\title{
DEVELOPMENT AND CHARACTERIZATION OF CONTROLLED RELEASE FAMOTIDINE MATRIX TABLETS CONTAINING COMPLEXES
}

\author{
SHABNAM AIN ${ }^{* 1}$, BABITA KUMAR ${ }^{1}$, KAMLA PATHAK ${ }^{2}$ \\ ${ }^{1}$ Sanskar College of Pharmacy and Research, Ghaziabad, ${ }^{2}$ College of Pharmacy, UP Rural Institute of Medical Sciences and Research, Saifai, \\ Etawah, Uttar Pradesh, India \\ Email: Shabnam.ain@sanskar.org \\ Received: 03 Apr 2017, Revised and Accepted: 14 Jun 2017
}

\begin{abstract}
Objective: The aim of the present study was to formulate the controlled release (CR) tablets of famotidine-cyclodextrin complexes to make the feasibility of complex in CR tablets and to access the kinetic of drug release mechanism

Methods: In this work the solubility study of famotidine was performed in various solvents like $0.1 \mathrm{~N} \mathrm{HCl}$, phosphate buffer pH 7.4 and distilled water. Enhancement of the solubility and dissolution rate of famotidine was done by complexation with cyclodextrin before formulation into controlled release tablets. Tablets were prepared in different batches by using different concentration of HPMC K15M (hydroxy propyl methyl cellulose) and EC (ethyl cellulose) polymers and polymer blend. All batches were evaluated for pre-compression and post-compression parameters.
\end{abstract} Release kinetics was analyzed using zero order, first order, higuchi, peppas and hixon-crowell model.

Results: All the formulation showed compliance with Pharmacopoeial standards. Release studies indicated that polymer blend (62\%HPMCK15M and $38 \% \mathrm{EC}$ ) based matrix tablets with complexed drug was able to control the release of famotidine up to $12 \mathrm{~h}$. Optimized formulation F13 containing complexed drug with same polymer blend showed zero order release and the release mechanism was predominant matrix swelling with erosion.

Conclusion: Results of the present study demonstrated that the drug: $\beta$-cyclodextrin complex would be a suitable candidate for preparing controlled release tablets of famotidine to improve drug solubility, flow properties and compressibility. Thus the complex used in matrix tablet is a promising approach to achieve appropriate controlled release dosage.

Keywords: Famotidine, Cyclodextrin, Matrix tablet, Complexation

(C) 2017 The Authors. Published by Innovare Academic Sciences Pvt Ltd. This is an open access article under the CC BY license (http://creativecommons.org/licenses/by/4.0/) DOI: http://dx.doi.org/10.22159/ijap.2017v9i4.18859

\section{INTRODUCTION}

Recent research work was done on the development of new drug delivery system in compare to development of new molecules [1, 2] because development cost of new drug molecule is very high [3]. For oral administration poorly water soluble drugs require high doses to attain therapeutic plasma concentrations. Low water solubility is the major problem in formulation development of new drug. Hence, various techniques can be used to improve the solubility of poorly water soluble drugs as well as to improve its dissolution and bioavailability. Micronization, chemical modification, solid dispersion, complexation, co-solvency, hydrotropy and micellar solubilization techniques are used to improve the solubility of poorly soluble drugs.

Cyclodextrin complexes play a very important role to enhance aqueous solubility and drug stability. Inclusion complex of poorly soluble drug with beta cyclodextrin increases the solubility in water and phosphate buffer also. Inclusion complexations are used to modify the physical and chemical properties of the drug molecule, in terms of water solubility $[4,5]$. Thus cyclodextrin is interesting polymer in many fields, especially pharmaceutical applications. Inclusion complexes of cyclodextrin with hydrophobic molecules are able to penetrate body tissues [6]; these can be used to release drug compounds under specific conditions. Natural polymers are the first choice for formulation of hydrophilic matrix system, providing robust mechanism due to choice of viscosity grades, reproducible release profile, cost effectiveness and utilization of existing conventional equipment and methods. Water penetration, polymer swelling, drug dissolution, drug diffusion and matrix erosion from dosage form is controlled by the hydration of natural polymer, which forms the gel barrier through which the drug diffuses [7, 8]. Because of the flexibility, matrix systems are widely used in oral controlled drug delivery systems to obtain a desirable drug release profile and broad regulatory acceptance [9]. Famotidine is a potent $\mathrm{H} 2$ receptor antagonist used for treatment of heartburn, ulcers, and esophagitis at daily doses from $10 \mathrm{mg}$ to $80 \mathrm{mg}$. Approved schedules of famotidine administration include 10 or 20 mg QD ('quaque die' means one a day) or BID ('bis in die' means twice a day) for treatment of heartburn, 20 $\mathrm{mg}$ or $40 \mathrm{mg}$ QD for healing ulcers, $20 \mathrm{mg}$ BID $(6 \mathrm{w})$ for treatment of gastroesophageal reflux disease and 20 or $40 \mathrm{mg}$ BID for treatment of esophageal erosion. For treatment of Zollinger-Ellison Syndrome (hypersecretion of gastric acid), doses of up to $800 \mathrm{mg} /$ day have been used. Famotidine has low water solubility $(0.271 \mathrm{mg} / \mathrm{ml})$. Therefore it requires multiple dosing for the treatment of gastric acid secretion for oral administration, which found to have many drawbacks, such as accumulation of drug in multidose therapy and poor patient compliance [10-12]. Controlled release formulations of famotidine can overcome some of these problems, while solubility enhancement increased bioavailability of famotidine $[13,14]$. The present research work was aimed to attempt the complex of famotidine with $\beta$ cyclodextrin by using kneading method and to evaluate by dissolution rate studies. Further it was confirmed by DSC (Differential Scanning calorimetry). Complex was used to formulate matrix tablets containing HPMC K15M and EC in different ratio. Optimization of formulations was done by dissolution studies.

\section{MATERIALS AND METHODS}

\section{Materials}

The drug famotidine was obtained as a gift sample from Uniplus Biotech Ltd, Assoda, $\beta$-cyclodextrin was obtained from Albert David Pvt Ltd, Ghaziabad, India. HPMC K15 and EC were procured from Central drug house (P) LTD, New Delhi. All other chemicals and solvents used were of pharmaceutical and analytical grade. Double distilled water was used throughout the study for experimental work.

\section{Methods}

Preliminary study

\section{FTIR (Fourier transform infrared) spectroscopic study}

FTIR spectrum of famotidine was recorded using Perkin Elmer Instrument spectrum one (model) FTIR spectrometer and compared with reference spectra of pure drug, famotidine $[10,15]$. 


\section{Equilibrium solubility study of pure drug}

Equilibrium solubility of the pure drug was determined in various solvents such as $0.1 \mathrm{~N} \mathrm{HCl}$, phosphate buffer $\mathrm{pH} 7.4$ and distilled water. For this excess amount of drug was dissolved in solvent and kept for shaking at constant temperature for $72 \mathrm{~h}$. Samples were collected at $24 \mathrm{~h}, 48 \mathrm{~h}$ and $72 \mathrm{~h}$. Absorbance of the sample was measured by UV spectrophotometer and drug concentration was calculated at equilibrium state.

\section{DSC (Drug excipients compatibility) study}

Drug excipients compatibility study of pure drug was also performed to check the interaction of the pure drug with the polymers such as HPMC K15M, EC and $\beta$-cyclodextrin. For the estimation of drugpolymer interaction, drug and polymer was mixed in 1:1, 1:0.50 and 1:0.75 ratios and kept for study under controlled condition and it was examined by FTIR and DSC $[15,16]$.

\section{Preparation of Famotidine, $\beta$-cyclodextrin inclusion complex}

It was prepared by kneading method [17, 18]. For this weigh famotidine and $\beta$-cyclodextrin in 1:1 molar ratio. Cyclodextrin was transferred to a glass mortar and small quantity of water: ethanol $(1: 1 \mathrm{v} / \mathrm{v}, 3 \mathrm{ml})$ solution was added to form a homogenous paste. Now the drug powder was slowly added to the paste and kneaded for $45 \mathrm{~min}$. During the kneading process few drops of water was also added to maintain the consistency. The resultant paste was dried and grounded well followed by passing through 66 no. sieve. Prepared complex was stored in desiccator [19].

\section{Characterization/Evaluation of prepared complex}

\section{Dissolution rate studies}

Prepared complex were evaluated for drug release using USP apparatus II (LABINDIA). It was performed in $900 \mathrm{ml}$ distilled water (pH 6.8), phosphate buffer (pH 7.4) and in $0.1 \mathrm{~N} \mathrm{HCl}(\mathrm{pH} \mathrm{1.2)} \mathrm{at} 50$ $\mathrm{rpm}$ (revolution per minute). Temperature was maintained at 37 ${ }^{\circ} \mathrm{C} \pm 0.5{ }^{\circ} \mathrm{C}$ throughout the study. $5 \mathrm{ml}$ of aliquots were withdrawn at fixed time interval and analyzed spectrophotometrically at $265 \mathrm{~nm}$.

\section{Differential scanning calorimetry}

Differential scanning calorimetry (DSC) was performed by Perkin Elmer DSC 6000 to evaluate the prepared complex. DSC thermogram of complex was compared with DSC thermograms of pure drug and pure cyclodextrin.

\section{Formulation of controlled release tablets}

Controlled release matrix tablets were prepared by hydrophilic and hydrophobic polymer with complexed drug. For this all the ingredients were weighed according to formula given in table 1 and mixed well. Now the granules were formed by adding the binder solution to the powder and passed through the 66 no. sieve. Prepared granules were dried in hot air oven at $60{ }^{\circ} \mathrm{C}$ and again passed through same sieve followed by compression [20-22].

\section{Pre-compression evaluation}

Various pre-compression parameters were evaluated for estimating the flow ability of powder.

Table 1: Composition of controlled release tablets of famotidine

\begin{tabular}{|c|c|c|c|c|c|c|c|c|c|c|c|c|c|}
\hline Ingredients (mg) & F1 & F2 & F3 & F4 & F5 & F6 & F7 & F8 & F9 & F10 & F11 & F12 & F13 \\
\hline Drug/Complex & 130 & 130 & 130 & 130 & 130 & 130 & 130 & 270 & 270 & 270 & 270 & 270 & 270 \\
\hline HPMC K15M & - & 65 & 97 & 130 & 15 & 47 & 80 & 65 & 97 & 130 & 15 & 47 & 80 \\
\hline EC & - & - & - & - & 50 & 50 & 50 & - & - & - & 50 & 50 & 50 \\
\hline Magnesium stearate & 10 & 10 & 10 & 10 & 10 & 10 & 10 & 10 & 10 & 10 & 10 & 10 & 10 \\
\hline Talc & 15 & 15 & 15 & 15 & 15 & 15 & 15 & 15 & 15 & 15 & 15 & 15 & 15 \\
\hline PVP K30 & 15 & 15 & 15 & 15 & 15 & 15 & 15 & 15 & 15 & 15 & 15 & 15 & 15 \\
\hline Lactose & 330 & 265 & 233 & 200 & 265 & 233 & 200 & 125 & 93 & 60 & 125 & 93 & 60 \\
\hline Total weight & 500 & 500 & 500 & 500 & 500 & 500 & 500 & 500 & 500 & 500 & 500 & 500 & 500 \\
\hline
\end{tabular}

F1: Pure drug without polymers (HPMC K15M, EC), F2-F4: Containing pure drug and polymer (HPMC K15M in 1:0.5, 1:0.75, 1:1 ratio), F5-F7: Containing pure drug and polymer blend (HPMC K15M+EC in 1:0.5, 1:0.75, 1:1 ratio), F8-10: Containing famotidine-cyclodextrin complex equivalent to pure drug and polymer (HPMC K15M in 1:0.5, 1:0.75, 1:1 ratio), F11-F13: Containing famotidine-cyclodextrin complex equivalent to pure drug and polymer blend (HPMC K15M+EC in 1:0.5, 1:0.75, 1:1 ratio)

\section{Angle of repose}

Flow property of pure drug, drug: $\beta$-cyclodextrin complex and granules were calculated by determining the angle of repose $(\theta)$.

$$
\operatorname{Tan} \theta=\frac{h}{r}
$$

Where, $\theta=$ angle of repose, $\mathrm{h}=$ height of pile, $\mathrm{r}=$ radius of pile

\section{Bulk density $[\rho b]$}

Bulk density of pure drug and prepared granules were determined by using the following formula:

$$
\text { Bulk density }=\frac{\text { Mass }[\mathrm{M}]}{\text { Bulk volume }[\mathrm{Vb}]}
$$

\section{Tapped density [ot]}

Tapped density of the drug powder and prepared granules was determined by using conventional tapping method using $10 \mathrm{ml}$ cylinder with the help of following formula:

$$
\text { Tapped density }=\frac{\text { Mass }[\mathrm{M}]}{\text { Tapped volume }[\mathrm{Vt}]}
$$

\section{Carr's index}

Carr's index or compressibility ratio of pure drug and prepared granules were calculated by using equation:

$$
\text { Percentage compressibility }=\frac{\text { Tapped density }- \text { Bulk density }}{\text { Tapped density }} \times 100
$$

\section{Hausner's ratio}

Hausner's ratio of drug powder and prepared granules were also calculated by using formula.

$$
\text { Hausner's ratio }=\frac{\text { Tapped density }}{\text { Bulk density }}
$$

Flow property of powder/granules on basis of various parameters was estimated according to the table 2 .

\section{Post-compression evaluation}

\section{Tablet thickness and diameter}

Thickness and diameter of the prepared tablets were measured by using the vernier calipers.

\section{Hardness testing}

Hardness of the prepared tablets was measured by using the monsanto hardness tester (Campbell electronics). Hardness of tablets may vary from $4 \mathrm{~kg} / \mathrm{cm}^{2}$ to $8 \mathrm{~kg} / \mathrm{cm}^{2}$.

\section{Friability}

Friability of the prepared tablets was determined by friability test apparatus (HICON New Delhi) by using the equation: 


$$
\text { Percentage friability }=\frac{\text { Initial weight }[\mathrm{Wi}]-\text { Final weight }[\mathrm{Wf}]}{\text { Initial weight }[\mathrm{Wi}]} \times 100
$$

Friability limit for tablets is NMT (not more than) $0.4 \%$ as per BP and NMT $8 \%$ as per USP.

\section{Weight variation}

Weight variation of prepared tablets was determined by taking the average weight of 20 tablets and compared with weight variation tolerance for uncoated tablets.

Table 2: Flow property and corresponding parameters

\begin{tabular}{llll}
\hline Flow property & Parameters & & \\
\cline { 2 - 4 } & Angle of repose [ $\left.{ }^{\circ}\right]^{\prime}$ & Hausner's ratio & Carr's index [\%] \\
\hline Excellent & $25-30$ & $1-1.11$ & $<10$ \\
Good & $31-35$ & $1.12-1.18$ & $11-15$ \\
Fair & $36-40$ & $1.19-1.25$ & $16-20$ \\
Passable & $41-45$ & $1.26-1.34$ & $21-25$ \\
Poor & $46-55$ & $1.35-1.45$ & $26-31$ \\
Very poor & $56-65$ & $1.46-1,59$ & $32-37$ \\
Very very poor & $>66$ & $>1.60$ & $>38$ \\
\hline
\end{tabular}

Table 3: Weight variation tolerance for uncoated tablets

\begin{tabular}{lll}
\hline Maximum \% difference & Average weight of tablets & \\
\hline & IP/BP USP & $<130 \mathrm{mg}$ \\
10 & $<80 \mathrm{mg}$ & $130 \mathrm{mg}-324 \mathrm{mg}$ \\
7.5 & $80 \mathrm{mg}-250 \mathrm{mg}$ & $>324 \mathrm{mg}$ \\
5
\end{tabular}

\section{Content uniformity of drug}

Content uniformity of the tablet was analyzed by taking the drug in suitable diluents medium (phosphate buffer $\mathrm{pH}$ 7.4) and determining the absorbance of the solution at $265 \mathrm{~nm}$. Drug content was calculated by using equation:

$$
\begin{aligned}
& \text { Drug content } \\
& =\underline{\text { Concentration } \times \text { Dilution factor } \times \text { Initial amount of drug [mg] }}
\end{aligned}
$$

\section{Swelling index}

Swelling index of the tablets was calculated by soaking the tablet in phosphate buffer $\mathrm{pH} 7.4$ for two hours by using the equation:

$$
\text { Swelling index }=\frac{\text { Final weight }[\mathrm{Wf}]-\text { Initial weight }[\mathrm{Wi}]}{\text { Final weight }[\mathrm{Wf}]} \times 100
$$

\section{In vitro dissolution studies}

Dissolution study of prepared tablets were carried out in USP dissolution apparatus II (LABINDIA) in $0.1 \mathrm{~N} \mathrm{HCl} \mathrm{(pH} \mathrm{1.2)} \mathrm{and}$ phosphate buffer $\mathrm{pH}$ 7.4. Samples were withdrawn at specific time intervals and analyzed spectrophotometrically at $265 \mathrm{~nm}$ [22-24]. The amount of drug release was calculated by using the equation:

$$
\text { Percentage drug release }=\frac{\mathrm{C} \times \mathrm{DF} \times \mathrm{V}}{\mathrm{Wa} \times 1000} \times 100
$$

Where, $\mathrm{C}=$ concentration, $\mathrm{DF}=$ dilution factor, $\mathrm{V}=$ volume of dissolution medium,

\section{Wa = amount of drug}

\section{Mechanism of drug release}

Drug release kinetic study was performed by various model dependent parameters, namely zero order, first order, Hixoncrowell, korsemeyer and peppas etc. [25, 26].

\section{- Zero order model}

A zero order release would be predicted by the equation

$$
\mathrm{Qt}=\mathrm{Q} 0+\mathrm{K} 0 \mathrm{t}
$$

Where $\mathrm{Qt}=$ amount of drug dissolved in time $\mathrm{t}, \mathrm{Q} 0=$ initial amount of the drug in solution, $\mathrm{K} 0=$ zero order release constant

\section{- First order model}

First order release was calculated by using equation:

$\log \mathrm{C}=\log \mathrm{C} 0-\mathrm{Kt} / 2.303$
Where, $\mathrm{C} 0$ = initial concentration of drug, $\mathrm{K}=$ first order rate constant

\section{- Higuchi model}

Drug release from the matrix devices by diffusion has been described by equation:

$$
\mathrm{ft}=\mathrm{Q}=\mathrm{KH}^{*} \mathrm{t}_{1 / 2}
$$

Where, $\mathrm{Q}$ is Percentage of drug release at time $\mathrm{t}$

$\mathrm{KH}$ is Higuchi dissolution constant

\section{- Hixon-Crowell model}

Hixon and Crowell derived an equation for kinetic study in 1931.

$$
\mathrm{W} 01 / 3-\mathrm{Wt} 1 / 3=\kappa \mathrm{t}
$$

Where, $\mathrm{W} 0$ is initial amount of drug in dosage form at time $\mathrm{t}$

$\mathrm{Wt}$ is remaining amount of drug in dosage form at time $t$

$\mathrm{K}$ is surface volume relation constant

\section{- Korsmeyer-peppas model}

Korsmeyer derived a relationship which is used to describe drug release from a polymeric system. This relationship is described in equation:

$$
\mathrm{Mt} / \mathrm{M} \infty=\mathrm{Ktn}
$$

Where, $\mathrm{Mt} / \mathrm{M} \infty=$ fraction of drug released at time $\mathrm{t}$

$\mathrm{K}=$ release rate constant, $\mathrm{n}=$ release exponent

\section{Stability study}

Selected formulations were kept for $90 \mathrm{~d}$ in a stability chamber under controlled temperature and moisture. Temperature was kept $40 \pm 50{ }^{\circ} \mathrm{C}$ and humidity was maintained at $70 \pm 2 \%$. Samples were withdrawn at 0 , 30 and $90 \mathrm{~d}$ interval and evaluated for various parameters such as physical appearance (change in colour), absorption maxima and drug content. [16, 27]. All studies have been performed in triplicate.

\section{RESULTS AND DISCUSSION}

\section{Preliminary studies}

\section{FTIR spectroscopic study}

In FTIR spectra, strong bands were observed at $1638 \mathrm{~cm}^{-1}, 1534 \mathrm{~cm}$ $1,1331 \mathrm{~cm}^{-1}$ and $1320 \mathrm{~cm}^{-1}$, which confirms the presence of imine, amine and sulfonyl group in the compound, as shown in fig. 1. Hence it proves the identity of pure drug. 


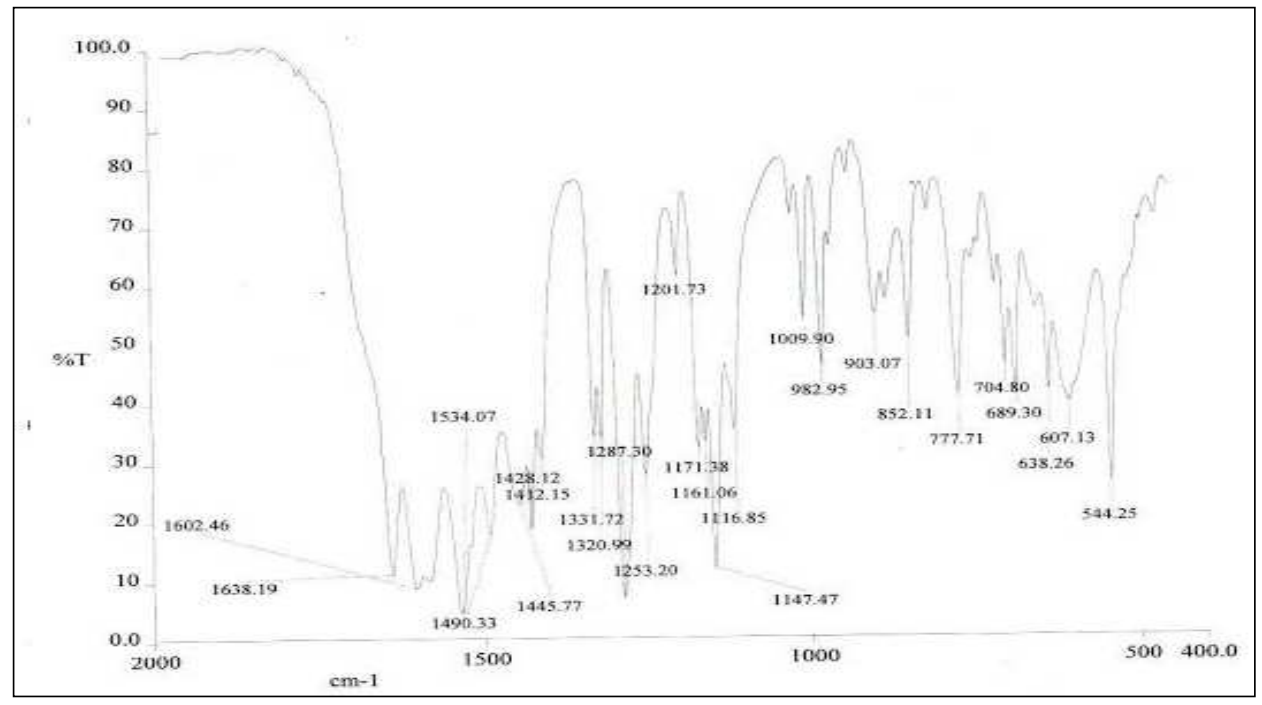

Fig. 1: Observed FTIR spectra of pure drug (famotidine)

\section{Equilibrium solubility study of pure drug}

Equilibrium solubility of pure drug was determined in various solvents, such as $0.1 \mathrm{~N} \mathrm{HCl}$, phosphate buffer $\mathrm{pH} 7.4$ and in distilled water by using UV spectrophotometer represented in table 4. Pure drug was found to be practically insoluble in distilled water as the solubility was found to be $69 \mu \mathrm{g} / \mathrm{ml}$ at equilibrium state. In $0.1 \mathrm{~N} \mathrm{HCl}$ drug solubility was found to be $780 \mu \mathrm{g} / \mathrm{ml}$, which indicates that drug is highly soluble in acidic media.

Table 4: Equilibrium solubility study of famotidine in different media

\begin{tabular}{ll}
\hline Solvent & Solubility $(\boldsymbol{\mu g} / \mathbf{m l})$ \\
\hline $0.1 \mathrm{~N} \mathrm{HCl}$ & 780 \\
Phosphate buffer pH 7.4 & 203 \\
Distilled water & 69 \\
\hline
\end{tabular}

\section{Drug excipients compatibility test}

On comparing the FTIR spectra of pure drug with drug: $\beta$ cyclodextrin, drug: HPMC K15M and drug: EC showed in fig. 2-5, no changes were observed in the bands of group present in famotidine which indicates the absence of any interaction. Hence it was confirmed by the compatibility test that there was no interaction of drug with polymers ( $\beta$-Cyclodextrin, HPMC K15M and EC).

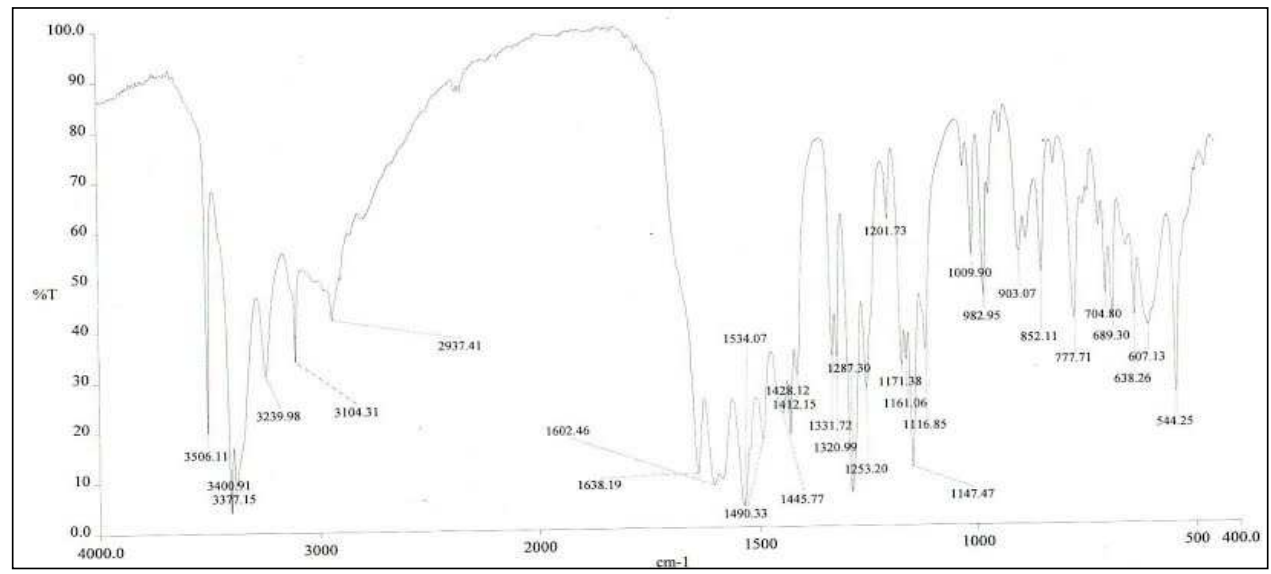

Fig. 2: FTIR spectra of pure drug

\section{Evaluation of prepared complex}

\section{Dissolution rate studies}

Prepared complexes were evaluated for drug release in different media and compared with pure drug as listed in table 5. Result showed that complex enhanced the drug release in all media. In distilled water it enhanced the release up to 1.6 folds, in phosphate buffer up to 2.04 folds and in $0.1 \mathrm{~N} \mathrm{HCl}$ up to 2.5 . It was indicated that complexation of poorly soluble drug was able to enhance the solubility of drug. 


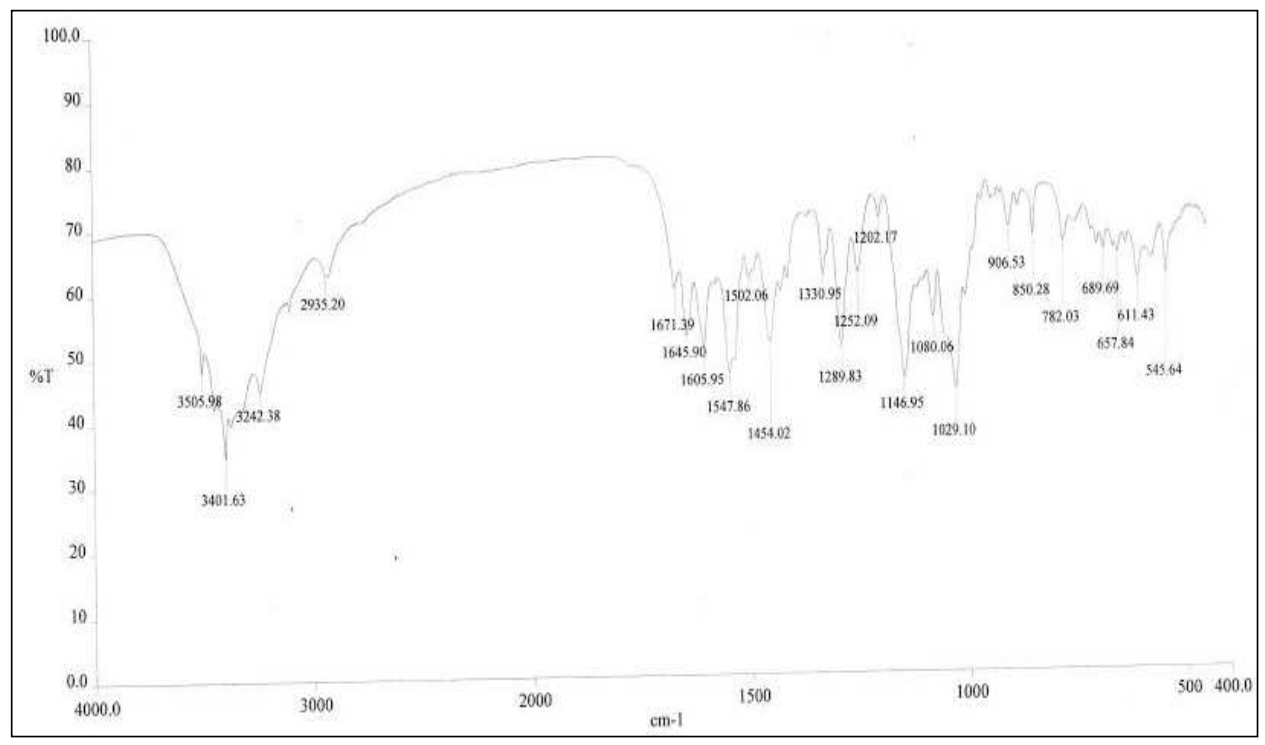

Fig. 3: FTIR spectra of famotidine: $\beta$-cyclodextrin

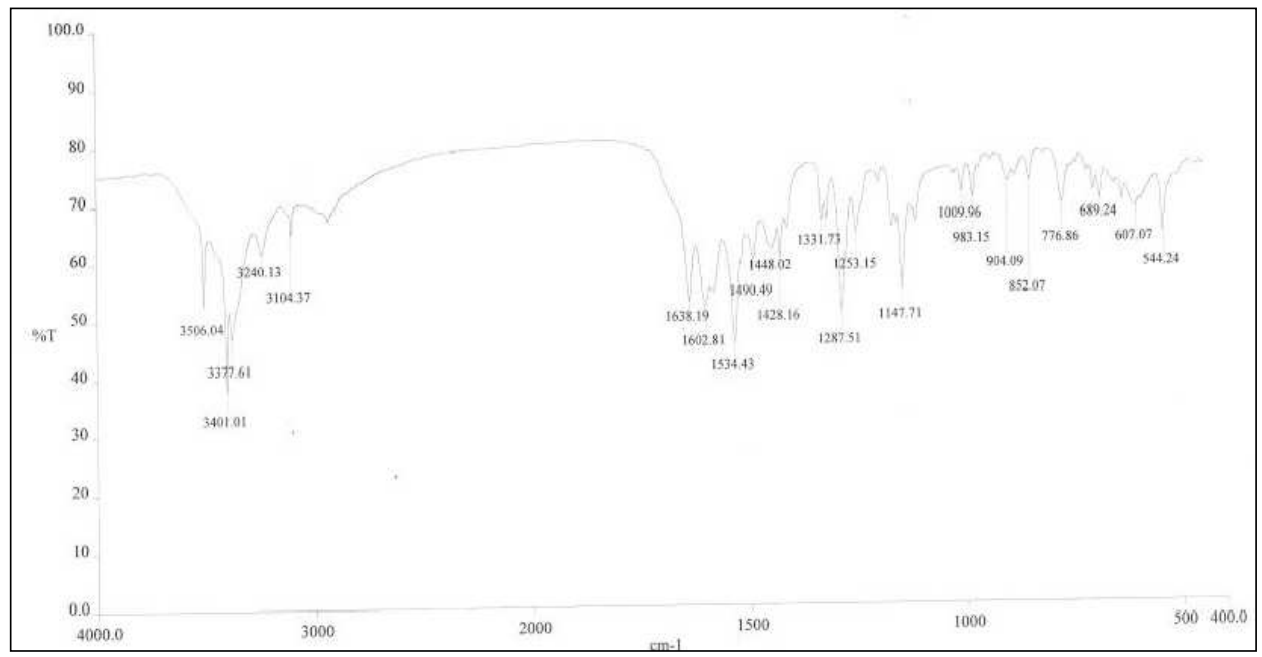

Fig. 4: FTIR spectra of famotidine: HPMC K15M

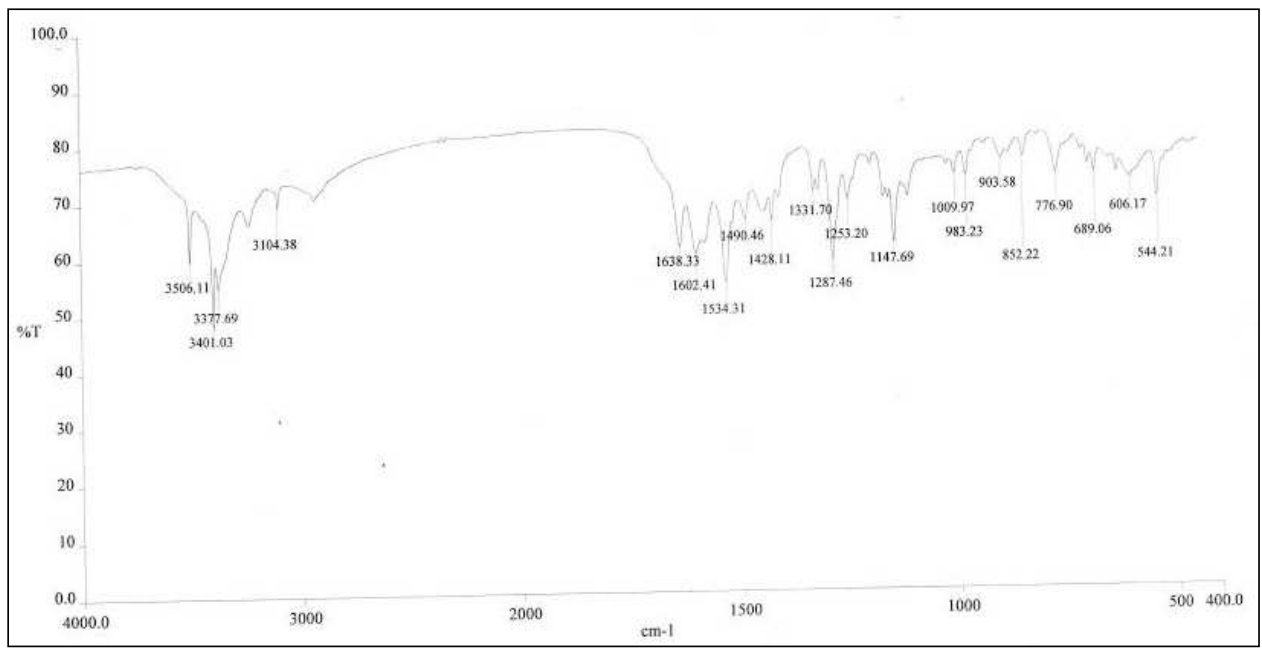

Fig. 5: FTIR spectra of famotidine: EC 
Table 5: \% cumulative drug release of drug from complex in different media

\begin{tabular}{|c|c|c|c|c|c|c|}
\hline \multirow{3}{*}{$\begin{array}{l}\text { Time (h) } \\
\text { Distilled water }\end{array}$} & \multicolumn{6}{|c|}{$\%$ cumulative drug release solvent } \\
\hline & & & Phosphate & & $0.1 \mathrm{~N} \mathrm{HCl}$ & \\
\hline & D1 & C1 & D2 & $\mathrm{C} 2$ & D3 & C3 \\
\hline 0 & 0 & 0 & 0 & 0 & 0 & 0 \\
\hline 0.5 & $4.94 \pm 0.02$ & $9.41 \pm 0.22$ & $10.92 \pm 0.11$ & $20.94 \pm 0.02$ & $13.09 \pm 0.12$ & $24.25 \pm 0.02$ \\
\hline 1 & $9.09 \pm 0.05$ & $15.2 \pm 0.01$ & $17.08 \pm 0.06$ & $34.97 \pm 0.05$ & $32.02 \pm 0.22$ & $75.38 \pm 0.05$ \\
\hline 2 & $15.12 \pm 0.12$ & $20.83 \pm 0.30$ & $35.9 \pm 0.41$ & $70.57 \pm 0.02$ & $74.5 \pm 0.05$ & \\
\hline 4 & $28.2 \pm 0.31$ & $38.38 \pm 0.12$ & $46.28 \pm 0.21$ & $82.48 \pm 0.12$ & & \\
\hline
\end{tabular}

$\mathrm{D}=$ Pure drug, $\mathrm{C}=$ Complexed drug, Data expressed, mean \pm standard deviation $(\mathrm{SD}, \mathrm{N}=3$ )

\section{Differential scanning calorimetry (DSC)}

The DSC thermograms of famotidine, kneaded complex and beta cyclodextrin were presented in fig. 6. Famotidine showed the behaviour of non-hygroscopic crystalline drug with a characteristic peak at $166^{\circ} \mathrm{C}$
$(\Delta \mathrm{H}=331.852 \mathrm{~J} / \mathrm{g})$ corresponding to its melting point. Famotidine melting point was also observed in the kneaded complex but $\Delta H$ value $(58.64 \mathrm{~J} / \mathrm{g})$ was lower than that of the pure drug and the intensity of thermal peak of drug was strongly reduced and broadened in the kneaded product. This indicates the formation of an inclusion complex.

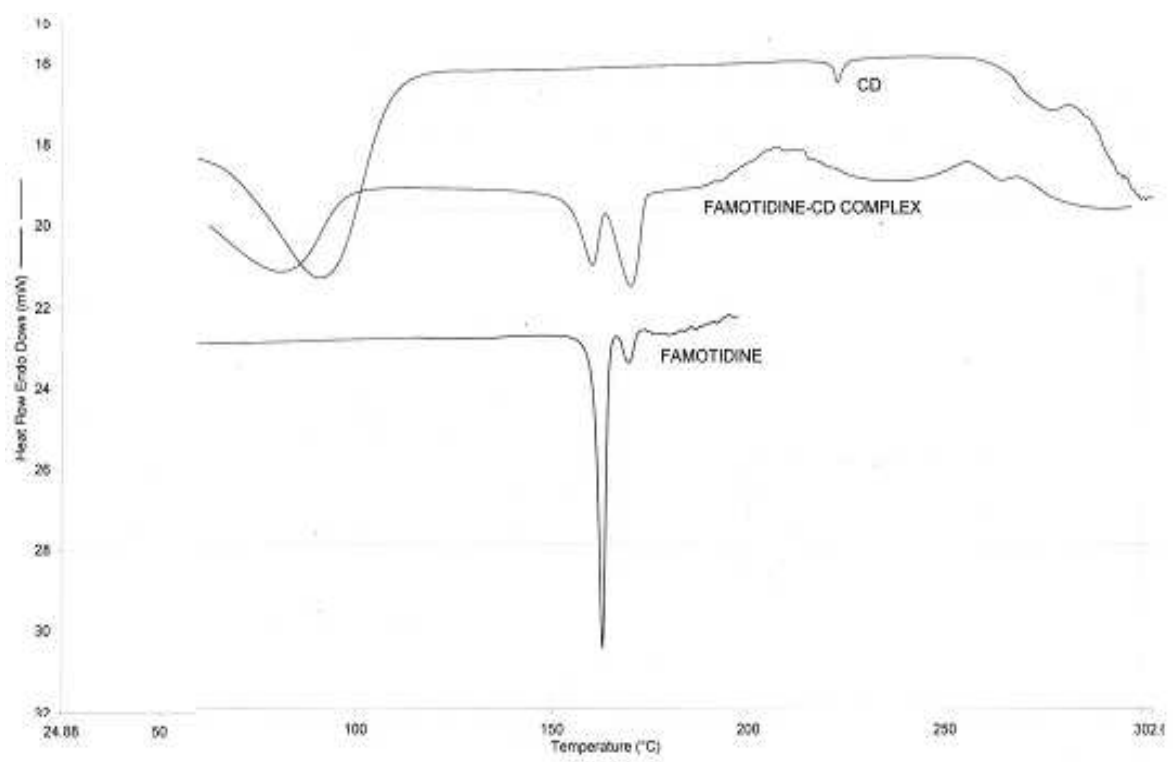

Fig. 6: Comparative DSC thermograms of pure drug (famotidine), pure CD (cyclodextrin) and famotidine-CD complex (kneaded product)

Table 6: Pre-compression parameters

\begin{tabular}{|c|c|c|c|c|c|}
\hline Formulation code & Angle of repose & Bulk density (gm/ml) & Tapped density (gm/ml) & Carr's Index & Hausner's ratio \\
\hline F1 & $40.67 \pm 0.006$ & $0.263 \pm 0.005$ & $0.412 \pm 0.001$ & $35.32 \pm 0.011$ & $1.52 \pm 0.001$ \\
\hline $\mathrm{F} 2$ & $41.23 \pm 0.012$ & $0.261 \pm 0.001$ & $0.423 \pm 0.004$ & $38.29 \pm 0.032$ & $1.62 \pm 0.020$ \\
\hline F3 & $43.23 \pm 0.020$ & $0.288 \pm 0.004$ & $0.451 \pm 0.005$ & $36.16 \pm .022$ & $1.57 \pm 0.022$ \\
\hline F4 & $40.68 \pm 0.011$ & $0.272 \pm 0.002$ & $0.431 \pm 0.005$ & $36.89 \pm 0.024$ & $1.58 \pm 0.011$ \\
\hline F5 & $43.28 \pm 0.015$ & $0.265 \pm 0.003$ & $0.418 \pm 0.002$ & $36.60 \pm 0.022$ & $1.57 \pm 0.005$ \\
\hline F6 & $41.23 \pm 0.015$ & $0.283 \pm 0.002$ & $0.430 \pm 0.002$ & $34.18 \pm 0.032$ & $1.51 \pm 0.024$ \\
\hline F7 & $40.54 \pm 0.032$ & $0.278 \pm 0.002$ & $0.438 \pm 0.003$ & $36.52 \pm 0.013$ & $1.57 \pm 0.032$ \\
\hline F8 & $32.75 \pm 0.025$ & $0.261 \pm 0.002$ & $0.323 \pm 0.003$ & $19.23 \pm 0.010$ & $1.24 \pm 0.021$ \\
\hline F9 & $31.72 \pm 0.210$ & $0.251 \pm 0.002$ & $0.319 \pm 0.003$ & $21.31 \pm 0.041$ & $1.27 \pm 0.022$ \\
\hline F10 & $34.23 \pm 0.022$ & $0.278 \pm 0.001$ & $0.356 \pm 0.002$ & $21.91 \pm 0.062$ & $1.28 \pm 0.021$ \\
\hline F11 & $33.23 \pm 0.020$ & $0.267 \pm 0.001$ & $0.324 \pm 0.001$ & $17.59 \pm 0.033$ & $1.21 \pm 0.024$ \\
\hline F12 & $32.22 \pm 0.021$ & $0.262 \pm 0.001$ & $0.325 \pm 0.001$ & $19.38 \pm 0.022$ & $1.24 \pm 0.011$ \\
\hline F13 & $31.65 \pm 0.021$ & $0.261 \pm 0.001$ & $0.322 \pm 0.001$ & $19.12 \pm 0.212$ & $1.22 \pm 0.021$ \\
\hline
\end{tabular}

Data are expressed in mean \pm standard deviation $(\mathrm{SD}, \mathrm{N}=3$ )

\section{Evaluation of controlled release tablets}

All batches were evaluated for pre-compression parameters (table 6) and post-compression parameters (table 7).

\section{Pre-compression evaluation}

Pre-compression parameters such as angle of repose, bulk density, tapped density, flow rate, hausner's ratio and carr's index of all formulations were reported in table 6 and it was found that granules of formulations containing drug- $\beta$ CD complex showed better flow ability rather than the formulations containing pure drug.

\section{Post-compression evaluation}

All formulations were evaluated for various post-compression parameters like thickness of tablets, hardness of tablets, uniformity of weight, friability, drug content, swelling index (fig. 7) and 
percentage drug release and the results were recorded in table7. All parameters were complied within the Pharmacopoeial standards. Swelling index was found in between 35.92 to 67.33. On comparing the formulation containing pure drug (F2, F3, F4, F5, F6 and F7) with the formulations containing drug- $\beta$-cyclodextrin complex (F8, F9, F10, F11, F12 and F13) it was found that tablets containing complex showed higher swelling index rather than the formulations with pure drug.

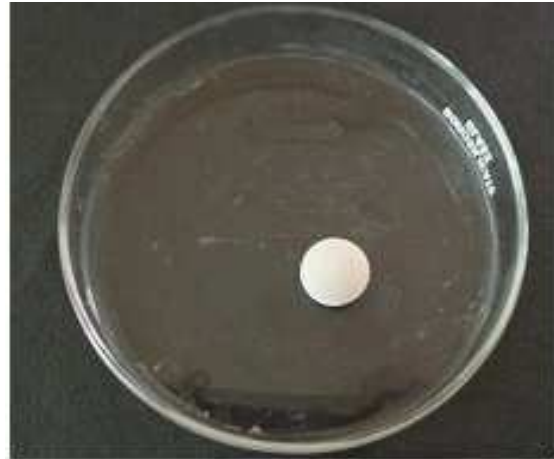

before swelling

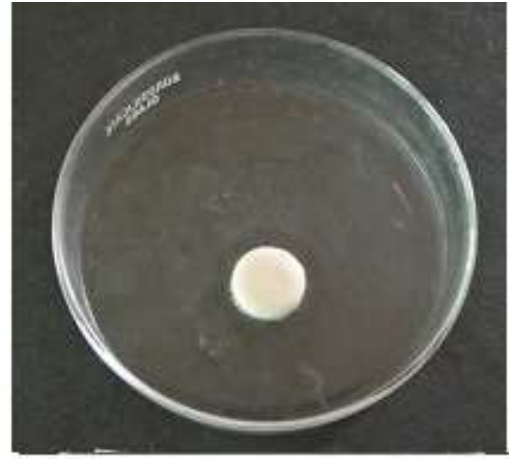

after swelling

Fig. 7: Tablet image before and after swelling

Table 7: Post-compression parameters

\begin{tabular}{|c|c|c|c|c|c|c|c|}
\hline Formulation & $\begin{array}{l}\text { Thickness } \\
\text { (cm) }\end{array}$ & $\begin{array}{l}\text { Diameter } \\
(\mathrm{cm})\end{array}$ & $\begin{array}{l}\text { Hardness } \\
\left(\mathrm{kg} / \mathrm{cm}^{2}\right)\end{array}$ & $\begin{array}{l}\text { Weight variation } \\
\text { (mg) }\end{array}$ & Friability & $\begin{array}{l}\text { Swelling } \\
\text { index }\end{array}$ & $\begin{array}{l}\text { Drug } \\
\text { content }\end{array}$ \\
\hline F1 & $0.48 \pm 0.01$ & $1.32 \pm 0.01$ & $5.33 \pm 0.58$ & $490.67 \pm 0.76$ & $0.39 \pm 0.02$ & $35.92 \pm 0.88$ & $96.65 \pm 0.04$ \\
\hline F2 & $0.48 \pm 0.01$ & $1.33 \pm 0.01$ & $5.33 \pm 0.58$ & $502.64 \pm 0.53$ & $0.37 \pm 0.02$ & $52.35 \pm 0.03$ & $97.55 \pm 0.29$ \\
\hline F3 & $0.48 \pm 0.01$ & $1.33 \pm 0.01$ & $5.33 \pm 0.58$ & $510.53 \pm 0.52$ & $0.28 \pm 0.02$ & $51.25 \pm 0.02$ & $97.92 \pm 0.83$ \\
\hline $\mathrm{F} 4$ & $0.48 \pm 0.01$ & $1.33 \pm 0.01$ & $5.33 \pm 0.58$ & $511.47 \pm 0.61$ & $0.42 \pm 0.03$ & $50.34 \pm 0.02$ & $95.72 \pm 0.57$ \\
\hline F5 & $0.48 \pm 0.01$ & $1.33 \pm 0.01$ & $5.33 \pm 0.58$ & $495.72 \pm 0.61$ & $0.38 \pm 0.02$ & $55.91 \pm 0.86$ & $96.49 \pm 1.18$ \\
\hline F6 & $0.48 \pm 0.01$ & $1.33 \pm 0.01$ & $5.67 \pm 0.58$ & $498.12 \pm 0.22$ & $0.57 \pm 0.04$ & $54.43 \pm 0.03$ & $97.74 \pm 1.02$ \\
\hline F7 & $0.48 \pm 0.01$ & $1.33 \pm 0.01$ & $5.67 \pm 0.58$ & $491.51 \pm 0.51$ & $0.78 \pm 0.01$ & $52.33 \pm 0.01$ & $96.42 \pm 1.01$ \\
\hline F8 & $0.48 \pm 0.01$ & $1.33 \pm 0.01$ & $5.67 \pm 0.58$ & $497.82 \pm 0.81$ & $0.55 \pm 0.04$ & $66.34 \pm 0.02$ & $97.89 \pm 0.56$ \\
\hline F9 & $0.48 \pm 0.01$ & $1.33 \pm 0.01$ & $5.33 \pm 0.58$ & $512.21 \pm 0.85$ & $0.45 \pm 0.04$ & $65.67 \pm 0.02$ & $98.40 \pm 0.73$ \\
\hline F10 & $0.48 \pm 0.01$ & $1.32 \pm 0.01$ & $5.67 \pm 0.58$ & $511.12 \pm 0.85$ & $0.53 \pm 0.04$ & $66.98 \pm 0.01$ & $96.42 \pm 1.01$ \\
\hline F11 & $0.48 \pm 0.01$ & $1.34 \pm 0.01$ & $5.33 \pm 0.58$ & $497.67 \pm 0.76$ & $0.43 \pm 0.03$ & $66.87 \pm 0.01$ & $96.48 \pm 1.18$ \\
\hline F12 & $0.48 \pm 0.01$ & $1.33 \pm 0.01$ & $5.67 \pm 0.58$ & $500.93 \pm 1.01$ & $0.38 \pm 0.02$ & $67.33 \pm 0.58$ & $98.78 \pm 0.77$ \\
\hline F13 & $0.48 \pm 0.01$ & $1.32 \pm 0.01$ & $5.67 \pm 0.58$ & $497.56 \pm 0.59$ & $0.76 \pm 0.05$ & $65.45 \pm 0.02$ & $96.80 \pm 1.60$ \\
\hline
\end{tabular}

Data are expressed in mean \pm standard deviation $(\mathrm{SD}, \mathrm{N}=3$ )

\section{In vitro dissolution test}

The release profile of famotidine controlled release matrix tablets from different batches were illustrated in table 8 and fig. 8. Formulation F7 containing 62\% HPMCK15M and 38\% EC showed 88.02\% release within $12 \mathrm{~h}$ of dissolution study and formulation F13 containing complexed drug with same polymer blend ratio showed $98.92 \%$ release that was controlled up to $12 \mathrm{~h}$.
This may be due to a more rigid complex formed by hydrophilic polymers (HPMCK15M) when used in much concentrations along with the presence of EC which helped in retaining the drug in the matrix and did not allowed rapid diffusion of soluble drug from the matrix. Hence the F13 formulation was the best formulation based on controlling the release rate for $12 \mathrm{~h}$ and cyclodextrin can be used as a better tool for enhancing the drug release over a long term period in controlled manner.

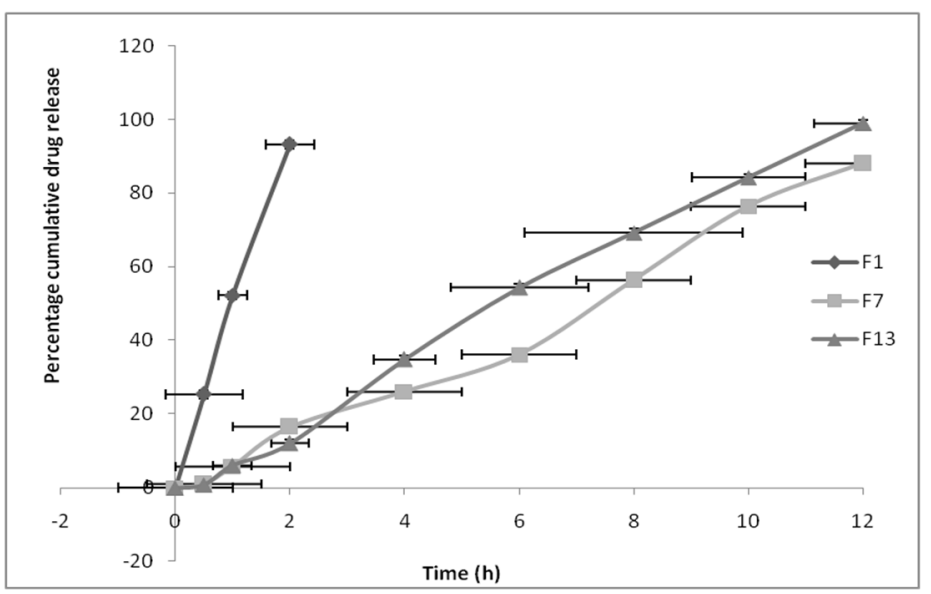

Fig. 8: \% drug release $\pm S D$ of selected formulations at different time intervals 
Table 8: In vitro release of famotidine controlled release matrix tablet formulations

\begin{tabular}{|c|c|c|c|c|c|c|c|c|c|c|c|c|c|}
\hline $\begin{array}{l}\text { Ti } \\
\text { me } \\
\text { (h) }\end{array}$ & F1 & F2 & F3 & F4 & F5 & F6 & F7 & F8 & F9 & F10 & F11 & F12 & F13 \\
\hline 0 & 0 & 0 & 0 & 0 & 0 & 0 & 0 & 0 & 0 & 0 & 0 & 0 & 0 \\
\hline 0.5 & $\begin{array}{l}25.33 \pm \\
0.67\end{array}$ & $\begin{array}{l}4.34 \pm 0 . \\
40\end{array}$ & $\begin{array}{l}3.76 \pm 0 . \\
21\end{array}$ & $\begin{array}{l}3.93 \pm 0 . \\
31\end{array}$ & $\begin{array}{l}2.12 \pm 1 \\
2\end{array}$ & $\begin{array}{l}3.59 \pm 1 \\
3\end{array}$ & $\begin{array}{l}1.01 \pm 0 . \\
81\end{array}$ & $\begin{array}{l}4.71 \pm 0 . \\
75\end{array}$ & $\begin{array}{l}4.93 \pm 0 \\
15\end{array}$ & $\begin{array}{l}4.77 \pm 0 \\
92\end{array}$ & $\begin{array}{l}1.93 \pm 0 \\
12\end{array}$ & $\begin{array}{l}1.01 \pm 0 . \\
92\end{array}$ & $\begin{array}{l}0.85 \pm 0 \\
12\end{array}$ \\
\hline 1 & $\begin{array}{l}52.21 \pm \\
0.25\end{array}$ & $\begin{array}{l}5.94 \pm 0 . \\
71\end{array}$ & $\begin{array}{l}5.61 \pm 0 . \\
61\end{array}$ & $\begin{array}{l}5.94 \pm 0 . \\
90\end{array}$ & $\begin{array}{l}6.25 \pm 0 . \\
15\end{array}$ & $\begin{array}{l}5.26 \pm 1 \\
2\end{array}$ & $\begin{array}{l}5.77 \pm 0 . \\
76\end{array}$ & $\begin{array}{l}6.82 \pm 0 \\
54\end{array}$ & $\begin{array}{l}6.93 \pm 0 . \\
22\end{array}$ & $\begin{array}{l}8.61 \pm 0 . \\
83\end{array}$ & $\begin{array}{l}6.19 \pm 1 \\
82\end{array}$ & $\begin{array}{l}6.92 \pm 0 . \\
12\end{array}$ & $\begin{array}{l}6.02 \pm 0 \\
34\end{array}$ \\
\hline 2 & $\begin{array}{l}93.18 \pm \\
0.42\end{array}$ & $\begin{array}{l}10.86 \pm \\
0.30\end{array}$ & $\begin{array}{l}13.55 \pm \\
10\end{array}$ & $\begin{array}{l}13.04 \pm \\
0.80\end{array}$ & $\begin{array}{l}16.09 \pm \\
0.25\end{array}$ & $\begin{array}{l}13.08 \pm \\
0.78\end{array}$ & $\begin{array}{l}16.54 \pm \\
0.66\end{array}$ & $\begin{array}{l}12.12 \pm \\
0.21\end{array}$ & $\begin{array}{l}13.21 \pm \\
0.34\end{array}$ & $\begin{array}{l}16.90 \pm \\
0.17\end{array}$ & $\begin{array}{l}15.43 \pm \\
1.10\end{array}$ & $\begin{array}{l}12.81 \pm \\
0.11\end{array}$ & $\begin{array}{l}12.04 \pm \\
0.33\end{array}$ \\
\hline 4 & - & $\begin{array}{l}26.42 \pm \\
0.91\end{array}$ & $\begin{array}{l}28.42 \pm \\
0.70\end{array}$ & $\begin{array}{l}30.76 \pm \\
1.21\end{array}$ & $\begin{array}{l}35.12 \pm \\
0.81\end{array}$ & $\begin{array}{l}27.00 \pm \\
0.56\end{array}$ & $\begin{array}{l}26.09 \pm \\
0.54\end{array}$ & $\begin{array}{l}27.75 \pm \\
0.62\end{array}$ & $\begin{array}{l}28.09 \pm \\
0.25\end{array}$ & $\begin{array}{l}29.42 \pm \\
1.31\end{array}$ & $\begin{array}{l}24.21 \pm \\
1.00\end{array}$ & $\begin{array}{l}20.79 \pm \\
1.21\end{array}$ & $\begin{array}{l}34.78 \pm \\
0.54\end{array}$ \\
\hline 6 & - & $\begin{array}{l}37.45 \pm \\
0.80\end{array}$ & $\begin{array}{l}32.11 \pm \\
0.61\end{array}$ & $\begin{array}{l}33.12 \pm \\
10\end{array}$ & $\begin{array}{l}42.34 \pm \\
0.92\end{array}$ & $\begin{array}{l}32.77 \pm \\
0.45\end{array}$ & $\begin{array}{l}36.12 \pm \\
1.61\end{array}$ & $\begin{array}{l}38.46 \pm \\
0.92\end{array}$ & $\begin{array}{l}42.81 \pm \\
0.91\end{array}$ & $\begin{array}{l}49.13 \pm \\
0.42\end{array}$ & $\begin{array}{l}45.43 \pm \\
0.98\end{array}$ & $\begin{array}{l}46.46 \pm \\
0.75\end{array}$ & $\begin{array}{l}54.29 \pm \\
1.23\end{array}$ \\
\hline 8 & - & $\begin{array}{l}40.46 \pm \\
11\end{array}$ & $\begin{array}{l}36.78 \pm \\
0.61\end{array}$ & $\begin{array}{l}37.79 \pm \\
0.92\end{array}$ & $\begin{array}{l}69.26 \pm \\
0.78\end{array}$ & $\begin{array}{l}37.12 \pm \\
0.76\end{array}$ & $\begin{array}{l}46.34 \pm \\
1.80\end{array}$ & $\begin{array}{l}44.15 \pm \\
0.82\end{array}$ & $\begin{array}{l}46.51 \pm \\
0.74\end{array}$ & $\begin{array}{l}63.48 \pm \\
0.22\end{array}$ & $\begin{array}{l}68.31 \pm \\
0.76\end{array}$ & $\begin{array}{l}63.65 \pm \\
0.91\end{array}$ & $\begin{array}{l}69.24 \pm \\
1.92\end{array}$ \\
\hline 10 & - & $\begin{array}{l}80.06 \pm \\
1.20\end{array}$ & $\begin{array}{l}82.29 \pm \\
0.52\end{array}$ & $\begin{array}{l}88.29 \pm \\
0.56\end{array}$ & $\begin{array}{l}86.23 \pm \\
0.25\end{array}$ & $\begin{array}{l}74.19 \pm \\
0.82\end{array}$ & $\begin{array}{l}76.42 \pm \\
1.21\end{array}$ & $\begin{array}{l}82.65 \pm \\
0.76\end{array}$ & $\begin{array}{l}86.95 \pm \\
0.16\end{array}$ & $\begin{array}{l}86.27 \pm \\
0.19\end{array}$ & $\begin{array}{l}79.11 \pm \\
0.62\end{array}$ & $\begin{array}{l}84.34 \pm \\
0.85\end{array}$ & $\begin{array}{l}84.21 \pm \\
0.99\end{array}$ \\
\hline 12 & - & - & - & $\begin{array}{l}92.35 \pm \\
0.54\end{array}$ & - & $\begin{array}{l}87.62 \pm \\
1.30\end{array}$ & $\begin{array}{l}88.02 \pm \\
1.31\end{array}$ & $\begin{array}{l}93.45 \pm \\
1.11\end{array}$ & $\begin{array}{l}97.24 \pm \\
0.11\end{array}$ & $\begin{array}{l}99.32 \pm \\
0.88\end{array}$ & $\begin{array}{l}82.21 \pm \\
1.11\end{array}$ & $\begin{array}{l}89.86 \pm \\
0.72\end{array}$ & $\begin{array}{l}98.92 \pm \\
0.86\end{array}$ \\
\hline
\end{tabular}

Data are expressed in mean \pm standard deviation $(\mathrm{SD}, \mathrm{N}=3$ )

\section{Drug release kinetic study}

The in vitro release pattern of the selected formulation was analyzed by fitting the dissolution data in to various kinetic models. From which it was concluded that formulation F13 followed zero order release (table 9) and the release mechanism was predominant matrix swelling and erosion. Therefore the drug release from prepared tablet is controlled by more than one process i.e. swelling of polymer followed by drug diffusion through the swelled polymer and slow erosion of the tablet. A correlation data showed that complex of drug with polymer blend (HPMC K15M and EC) was found to be more significant.

Table 9: Drug release kinetic study

\begin{tabular}{|c|c|c|c|c|c|}
\hline \multirow[t]{3}{*}{ Formulation } & \multicolumn{5}{|c|}{ Mathematical models } \\
\hline & \multicolumn{3}{|c|}{$\mathbf{r}^{2}$} & \multicolumn{2}{|l|}{$\mathbf{n}$} \\
\hline & Zero order & First order & Higuchi model & Peppas model & Peppas \\
\hline F7 & 0.8942 & 0.9562 & 0.8184 & 0.9242 & 0.8131 \\
\hline F13 & 0.9840 & 0.8024 & 0.8574 & 0.9421 & 0.8865 \\
\hline
\end{tabular}

\section{Scanning electron microscopy (SEM)}

Scanning electron microscopic study of the selected formulation was also carried for both conditions, normal tablet and swollen tablet (fig. 9). On observing the both images it was concluded that tablet matrix absorbed the solvent and formed a jelly like structure. As there was no jelly like structure was found in SEM image of normal tablet. It was confirmed that the drug release from the matrix tablet via swollen followed by erosion method.

\section{Stability study}

Selected formulations (F7and F13 showed in fig. 10) were kept for $90 \mathrm{~d}$ in stability chamber under controlled temperature and moisture. Temperature was kept $40 \pm 5{ }^{\circ} \mathrm{C}$ and humidity was maintained at $70 \pm 2 \%$. Samples were withdrawn at 0,30 and $90 \mathrm{~d}$ interval and evaluated for various parameters as listed in table 10. It was indicated that there were no significant changes observed in drug content and absorption maxima at the end of three mo period.

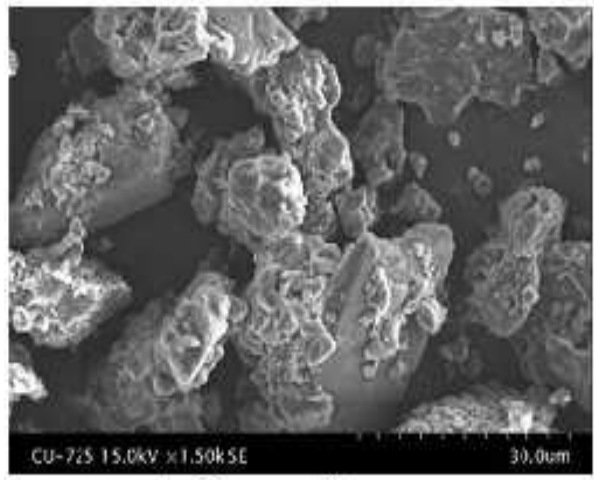

before swelling

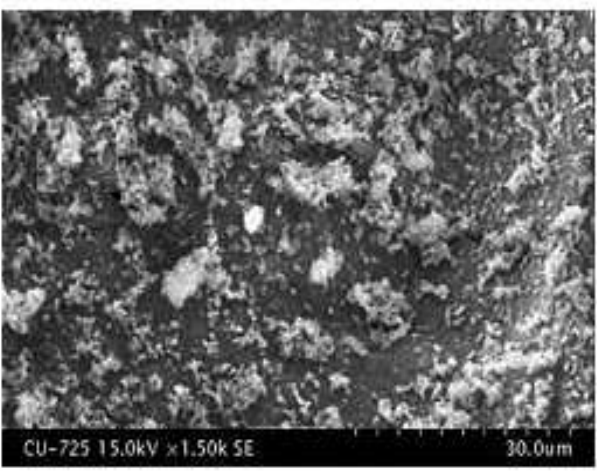

after swelling

Fig. 9: Scanning electron microscopy (SEM) of normal and swelled tablet 


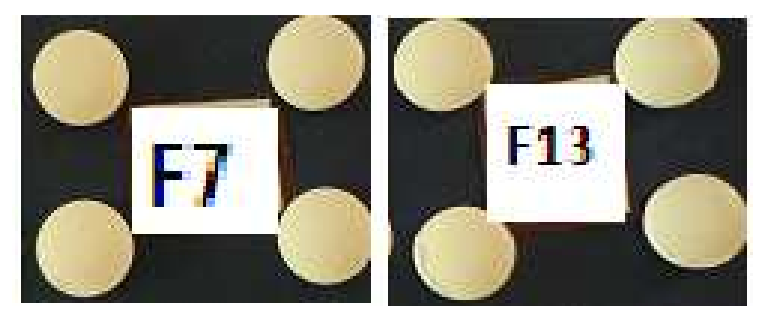

Fig. 10: Physical appearance of selected formulation

Table 10: Stability data of selected formulations

\begin{tabular}{|c|c|c|c|c|c|c|c|c|c|}
\hline \multirow[t]{2}{*}{ Formulation } & \multicolumn{3}{|l|}{ At $0 \mathrm{~d}$} & \multicolumn{3}{|l|}{ At $30 \mathrm{~d}$} & \multicolumn{3}{|l|}{ At $90 \mathrm{~d}$} \\
\hline & $\begin{array}{l}\text { Color } \\
\text { change }\end{array}$ & $\lambda_{\max }$ & $\begin{array}{l}\text { Drug } \\
\text { content }\end{array}$ & $\begin{array}{l}\text { Color } \\
\text { change }\end{array}$ & $\lambda_{\max }$ & $\begin{array}{l}\text { Drug } \\
\text { content }\end{array}$ & $\begin{array}{l}\text { Color } \\
\text { change }\end{array}$ & $\lambda_{\max }$ & $\begin{array}{l}\text { Drug } \\
\text { content }\end{array}$ \\
\hline F7 & No change & $266 \mathrm{~nm}$ & $96.49 \%$ & No change & $266 \mathrm{~nm}$ & $95.48 \%$ & No change & $266 \mathrm{~nm}$ & $95.20 \%$ \\
\hline F13 & No change & $266 \mathrm{~nm}$ & $98.78 \%$ & No change & $266 \mathrm{~nm}$ & $96.72 \%$ & No change & $266 \mathrm{~nm}$ & $96.14 \%$ \\
\hline
\end{tabular}

\section{CONCLUSION}

Results of the present study was concluded that the drug: $\beta$ cyclodextrin complex would be a suitable candidate for preparing controlled release tablets of famotidine to improve drug solubility, flow properties and compressibility. Release studies indicated that polymer blend ( $62 \%$ HPMC and $38 \%$ EC) based matrix tablets with drug and drug: $\beta$-cyclodextrin was able to control the release of famotidine up to $12 \mathrm{~h}$. Swelling with erosion might be the mechanism for drug release and the correlation data showed that F13 formulation followed zero order release was found to be more significant. Thus the complex used in matrix tablet is a promising approach to achieve appropriate controlled release dosage form.

\section{CONFLICT OF INTERESTS}

Declared none

\section{REFERENCES}

1. Robinson JR, Lee VHL. Controlled drug delivery fundamentals and applications. $2^{\text {nd }}$ edition. New York: Marcel Dekker; 1987.

2. Khan GM. Controlled release oral dosage forms: some recent advances in matrix type drug delivery systems. Sciences 2001;1:350-4.

3. Jain AK. Development and characterization of pioglitazonecyclodextrin based inclusion complex containing controlled release tablets. Int J Pharm Biol Res 2013;4:100-16.

4. Sachan NK, Pushkar S, Solanki SS, Bhatere DS. Enhancement of solubility of acyclovir by solid dispersion and inclusion complexation method. World Appl Sci J 2010;11:857-64.

5. Kurmi R, Mishra DK, Jain DK. Solid dispersion: a novel means of solubility enhancement. J Crit Rev 2016;3:1-8.

6. Szejtli J. Past present and future of cyclodextrin research. Pure Appl Chem 2004;76:1825-45.

7. Ashish KJ. Development and characterization of pioglitazone- $\beta$ cyclodextrin inclusion complex containing controlled release tablets. Int J Pharm Biol Res 2013;4:100-16.

8. Rajesh KJ, Yogesh KG, Rakesh KJ. Formulation development and evaluation of controlled release tablets of famotidine. Int J Pharm Biol Arch 2012;3:858-66.

9. Reddy KR, Mutalik S, Reddy S. Once-daily sustained-release matrix tablets of nicorandil: formulation and in vitro evaluation. AAPS PharmSciTech 2003;4:E61.

10. Indian Pharmacopoeia. Delhi: Controller of publications; 2010.

11. Drug information on line. Available from: http://www.drugs.com. [Last accessed on 01 Mar 2017]

12. Sweetman SC. Martindale: the complete drug reference. $33^{\text {rd }}$ edition. London: TPP; 2002.
13. Tapan KG, Kulesh K, Amit A, Ajazuddin HB, Dulal KT. A novel and alternative approach to controlled release drug delivery system based on solid dispersion technique. Bull Fac Pharm (Cario Univ) 2012;50:147-59.

14. Umarunisha AM, Rathinaraj BS, Arunachalam A, Bangale GS, Shinde GV, Umalkar DG. Design and evaluation of famotidine controlled release tablets. Int J Pharm Sci 2010;2:574-82.

15. Ajit K, Trushali M, Nagesh A. Application of novel natural polymer for controlling the release of fenoverine from controlled release matrix tablets. Int J Appl Pharm 2017;9:1-9.

16. Aulton ME. Pharmacetics: the science of dosage form design. $2^{\text {nd }}$ edition. New York: Churchill Livingstone; 2002.

17. Zingone G, Rubessa F. Preformulation study of the inclusion complex warfarin-cyclodextrin. Int J Pharm 2005;291:3-10.

18. Govindarajan R, Nagarsenkar MS. Influence of preparation methodology on solid-state properties of an acidic drugcyclodextrin system. J Pharm Pharmacol 2004;56:725-33.

19. Sarvana KK, Sushma M, Prasanna RY. Dissolution enhancement of poorly soluble drugs by using complexation technique. J Pharm Sci Res 2013;5:120-4.

20. Kumar A, Yeluri P, Rao S, Kuljarni SV, Kumar R. Formulation and in vitro evaluation of controlled release matrix tablet of lamivudine. J Global Pharma Technol 2010;2:52-9.

21. Sathish U, Shravani B, Raghavendra RNG, Srikanth RM, Sanjeev NB. Overview on controlled release dosage forms. Int J Pharm Sci 2013;3:258-69.

22. Mosab A. Approaches to achieve an oral controlled release drug delivery system using polymers: a recent review. Int J Pharm Pharm Sci 2015; 7:16-21.

23. The United States Pharmacopoeia 27 the National Formulary 22. Rockville: United States Pharmacopoeial Convention; 2004.

24. Ganesh K, Sree kanth J, Satyavati D. Formulation development and in vitro evaluation of sustained release matrix tablets of bosentan by using synthetic polymers. Int J Pharm Pharm Sci 2014;6:111-8.

25. Vyas SP, Khar RK. Controlled drug delivery concepts and advances. $1^{\text {st }}$ edition. Delhi: Vallabh Prakashan; 2006.

26. Das S, Murthy PN, Nath L, Chowdhury P. Kinetic modeling on drug release from controlled drug delivery systems. Acta Poloniae Pharm Drug Res 2010;67:217-23.

27. Ghosh S, Barik BB. Formulation and in vitro evaluation of once daily sustained release formulation of aceclofenac. Trop J Pharm Res 2010;9:265-73.

\section{How to cite this article}

- Shabnam Ain, Babita Kumar, Kamla Pathak. Development and characterization of controlled release famotidine matrix tablets containing complexes. Int J Appl Pharm 2017;9(4):38-46. 